\title{
Toxicidad aguda del piretroide cipermetrina en Poecilia reticulata y Cnesterodon decemmaculatus (Pisces, Poeciliidae)*
}

Parma de Croux, Ma. Julieta; Loteste, Alicia; Campana, Mirta

Instituto Nacional de Limnologia. José Maciá 1933. (3016) Santo Tomé. Santa Fe. Argentina. TE/FAX: 54-342-4750394. E-mail: inali@arnet.com.ar

RESUMEN: Se evaluó la toxicidad del piretroide cipermetrina, en Poecilia reticulata (Peters, 1859) y Cnesterodon decemmaculatus (Jenyns, 1842), mediante ensayos de laboratorio que se realizaron en recipientes de vidrio de 5 I de capacidad, utilizando 10 peces por concentración. Las concentraciones de exposición ensayadas fueron: 100,60, 36, 21,6 y $13 \mu \mathrm{g} / /$ para la primera especie y 7,8 ; 4,$7 ; 2,8 ; 1,7 ; 1,0 ;$ y $0,6 \mu \mathrm{g} / \mathrm{l}$ para la segunda. El valor de CL50-96 hs. fue de $46,4 \mu \mathrm{g} / \mathrm{I}(40,3-53,6)$ para $P$. reticulata y de $1,84 \mu \mathrm{g} /$ I $(1,58-2,14)$ para $C$. decemmaculatus. Con el incremento en las concentraciones, los peces evidenciaron signos de estrés con alteraciones en la cantidad y amplitud de los movimientos operculares, indicando las dificultades para respirar normalmente. Para P. reticulata la mortalidad al término del ensayo fue de sólo un $3 \%$ y para $C$. decemmaculatus $7 \%$ a la más baja concentración, de $13 \mathrm{mg} / \mathrm{l}$ y $0.6 \mathrm{mg} / \mathrm{l}$, respectivamente.

Palabras claves: Poeciliidae - Cipermetrina - Toxicidad aguda.

SUMMARY: Acute toxicity of cyphermethrin pyrethroid in Poecilia retilculata and Cnesterodon decemmaculatus (Pisces, Poecilidae). Parma de Croux, Ma. Julieta; Loteste, Alicia; Campana, Mirta. Acute toxicity of cyphermethrin pyrethroid in two Poeciliidae species, Preticulata (Peters, 1859) and C. decemmaculatus (Jenyns, 1842) was studied. The experience was carried out in aquaria of $5 \mathrm{I}$ with 10 fish in each concentration. The exposure concentrations were: $100,60,36,21,6$ and $13 \mu \mathrm{g} / \mathrm{f}$ for first species, and $7.8 ; 4.7 ; 2.8 ; 1.7 ; 1.0 ;$ y $0.6 \mu \mathrm{g} / \mathrm{l}$ for the second. The $\mathrm{LC} 50-96 \mathrm{~h}$ value was $46.4 \mu \mathrm{g} / \mathrm{l}(40.3-53.6)$ for $P$. reticulata and $1.84 \mu \mathrm{g} / \mathrm{l}(1.58-2.14)$ for $C$. decemmaculatus. In high concentrations, fish showed signs of stress and important alterations in opercular ventilation. At the end of the test the mortality to $P$. reticulata was $3 \%$ at $13 \mu g /$ and $7 \%$ for $C$. decemmaculatus at 0.6 $\mu \mathrm{g} / \mathrm{l}$.

Key words: Poeciliidae - Cyphermethrin - Acute toxicity. 